\title{
PENDIDIKAN TOLERANSI KEAGAMAAN: Studi Kasus SMA Muhammadiyah Kupang Nusa Tenggara Timur
}

\author{
Imam Tholkhah \\ Profesor Riset Pada Puslitbang Pendidikan Agama dan Keagamaan \\ Badan Litbang dan Diklat Kementerian Agama RI \\ Jln. M Husni Tamrin No. 6 Jakarta Pusat, \\ Email: itholkhah@yahoo.co.id
}

\begin{abstract}
Tulisan ini menggambarkan hasil studi kasus tentang pengembangan budaya toleransi keagamaan yang berlangsung pada SMA Muhammadiyah Kupang Nusa Tenggara Timur. Data dihimpun melalui wawancara dengan para guru, siswa dan kepala sekolah. Proses penelitian, termasuk studi literatur, observasi lapangan dan penulisan berlangsung mulai bulan Juli sampai Nopember 2012. Siswa SMA Muhammadiyah terdiri dari penganut Islam dan Kristen dan Katolik (Kristiani). Pengembangan budaya toleransi di SMA Muhammadiyah dilakukan sebagai bagian dari misi dakwah Islam yang inklusif, mencerdaskan siswa tanpa membedakan latarbelakang agama. Implementasi pengembangan budaya toleransi dilakukan dengan pendekatan budaya, yang bersifat adaptif dengan kondisi masyarakat sekitar sekolah yang beragama Kristiani. Pemahaman dan sikap toleransi antar siswa yang berbeda agama di SMA Muhammadiyah Kupang dikembangkan melalui proses intra dan ekstra kurikuler, sejak siswa masuk di sekolah Muhammadiyah. Hasilnya, siswa dari berbagai agama dapat bekerja sama, saling menghargai perbedaan agama, mengembangkan tradisi berdemokrasi di dalam dan di luar kelas. Di kelas, para siswa berbeda agama memperoleh pendidikan agamanya dan di ajarkan oleh guru yang seagama. Di luar kelas siswa didukung untuk mengadakan kegiatan keagamaan sesuai dengan agamanya masing-masing. Model pengembangan budaya toleransi di SMA Muhammadiyah dapat dipromosikan dan dijadikan sebagai contoh pengembangan budaya toleransi keagamaan untuk sekolah-sekolah yang sejenis.
\end{abstract}

Keyword: Pendidikan Toleransi Keagamaan, SMA Muhammadiyah; Kupang

\section{Abstraksi}

This paper describes the results of a case study of the development of a culture of religious tolerance in SMA Muhammadiyah Kupang of East Nusa Tenggara. Data was collected through interviews with teachers, students and principals. Research, including literature study, field observations and writing took place from July to November 2012. Students of SMA Muhammadiyah consist of adherents of Islam and Christianity, including Catholics. Development of a culture of tolerance in SMA Muhammadiyah was conducted as part of the inclusive mission of preaching Islam, to educate students regardless of religious background. Implementation of the development of a culture of tolerance is done with a cultural approach, which is adaptive to the conditions in surrounding, mostly-Christian communities. Understanding and tolerance among students of different religions in SMA Muhammadiyah Kupang is developed through a process of intra-and extra-curricular activities beginning when students enter school. As a result, students of various religions can work together, respect religious differences, and develop democratic traditions inside and outside the classroom. In class, students of different

Naskah diterima 2 Mei 2013. Revisi pertama, 20 Juni 2013. Revisi kedua, 10 Juli 2013 dan revisi terahir 3 Agustus 2013. 
religions obtain their religious education from teachers who are of that same religion. Outside the classroom students are supported in conducting religious activities according to their respective religions. This model of the development of a culture of tolerance in SMA Muhammadiyah can be promoted and used as an example of religious tolerance for the cultural development of similar schools.

Keywords: Development of Culture, Religious Tolerance, High School

\section{PENDAHULUAN}

Bangsa Indonesia memiliki umat beragama yang majemuk dan multikultur, terdiri dari umat Islam, Kristen, Katolik, Hindu, Budha dan Konghucu yang tersebar di sekitar 13.000 pulau besar dan kecil. ${ }^{1}$ Masing-masing umat memiliki berbagai kelompok penganut faham keagamaan yang berbeda. Kemajemukan umat beragama tersebut dapat menjadi potensi kekuatan negara karena memperkaya budaya bangsa. Setiap kelompok penganut faham keagamaan memiliki keunikan dan keunggulan nilai budaya masing-masing, yang dapat dirajut untuk saling melengkapi satu sama lain, sebagai mozaik budaya bangsa. ${ }^{2}$ Kemajemukan umat beragama juga dapat menjadi fondasi modal sosial membangun karakter bangsa yang beradab dan kompetitif, karena ajaran semua agama mendorong para penganutnya agar menjadi manusia yang berkarakter mulia. $^{3}$ Kemajemukan umat beragama juga mampu menyatukan berbagai ethnik bangsa Indonesia yang tersebar di berbagai daerah dan pulau. Kesamaan identitas keagamaan di sebuah pulau dapat mengikat kelompok etnik di berbagai pulau lain melalui rasa solidaritas kesamaan agama yang bersifat nasional. ${ }^{4}$ Lebih jauh, kemajemukan umat beragama dapat menjadi kekuatan impersonal dan kekuatan spiritual serta penjaga moral masing-masing

${ }^{1}$ Ainul Yakin. 2005. Pendidikan Multikultural - CrossCultural Understanding untuk Demokrasi dan Keadilan, Jakarta: Pilar, h. 4

${ }^{2}$ Imam Tholkhah dan Mursyid Ali (eds). 2002. Konflik Sosial bernuansa Agama di Indonesia.Jakarta: Puslitbang Kehidupan Beragama - Badan Litbang dan Diklat Kementerian Agama.

${ }^{3}$ Imam Tholkhah. 2008. Manusia, Agama dan Perdamaian.Jakarta: Alghazali, h. 67-70

${ }^{4}$ Imam Tholkhah. 2005. Mewaspadai dan Mencegah Konflik Antar Umat Beragama. Jakarta: Badan Litbang Agama dan Diklat Kementerian Agama. umatnya yang tidak nampak, terutama karena penganut agama memiliki keyakinan adanya misteri pengawasan dari Yang Maha Kuasa.

Namun dalam realita, potensi kekuatan tersebut belum terealisasi secara optimal. Nilai toleransi untuk merajut kemajemukan umat beragama belum nampak secara nyata. Konflik keagamaan disertai tindakan kekerasan dan anarkis antara umat beda faham keagamaan cenderung meningkat dalam kurun beberapa tahun belakangan ini. ${ }^{5}$ Kekerasan fisik atau non fisik sering terjadi karena salah satu penganut agama dinilai menyinggung atau menodai simbol-simbol keyakinan agama penganut agama lain. ${ }^{6}$ Secara historis, konflik keagamaan antara umat Islam dan Kristen di Indonesia nampak bersifat laten, kambuhan yang terkadang muncul dalam bentuk saling membunuh, merusak, intimidasi antar umat beragama, dan terkadang tenggelam seolaholah umat beragama dalam keadaan rukun, damai, aman dan tenteram. ${ }^{7}$

${ }^{5}$ Azyumardi Azra. 2011. "Radikalisme Keagamaan Dan Deradikalisasi” dalam Abdurrahman Mas'ud (ed), Kerukunan Umat Beragama dalam Sorotan: Refleksi dan Evaluasi 10 Tahun Kebijakan dan Program Pusat Kerukunan Umat Beragama. Jakarta: Pusat Kerukunan Umat Beragama, Sekretariat Jenderal Kemenag RI, h. 188- 204

${ }^{6}$ Di antara simbol-simbol keagamaan seperti tempat ibadah, kitab suci, tradisi, pakaian, pernyataan, lagu-lagu atau yel-yel khas keagamaan.

${ }^{7}$ Konflik keagamaan antar kelompok umat Islam dan Kristen, termasuk di Indonesia, memiliki akar historis yang panjang. Antara $1095-1272$ telah terjadi perang Salib antara kelompok Islam dan Kristen, yang memakan banyak korban di kedua belah pihak.Perang ini tentu ikut mempengaruhi adanya jarak sosial antara umat Islam dan Kristen di dunia dan di Indonesia. Jarak sosial antara penganut Islam dan Kristen di Indonesia juga dipertajam oleh pengalaman historis perjuangan nasionalisme umat Islam melawan penjajah Belanda. Meskipun perjuangan tersebut merupakan konflik antara penjajah dengan yang dijajah,tetapi karena bangsa Belanda beridentitas Kristen, dan kebijakan pemerintah Belanda dinilai oleh pejuang Islam lebih mendukung 
Fenomena tersebut, sebagaimana Agus Wibowo menunjukkan, bahwa pendidikan agama dan moral yang berlangsung selama ini masih ada kelemahan. Pendidikan agama sebagai sumber nilai etika dan moral bangsa tidak berdaya sepenuhnya untuk mewarnai kehidupan sehari hari. ${ }^{8}$ Berbagai pendidikan formal dan non formal belum optimal menanamkan sikap toleran peserta didik. Bhineka Tunggal Ika baru sebatas konsep yang tersusun indah dalam lantunan lagu, buku pelajaran dan dokumen kenegaraan. Nilai toleransi untuk hidup rukun, ramah, saling menghargai perbedaan, gotong-royong, saling pengertian, dan kerelaan untuk hidup secara damai dan harmoni ${ }^{9}$ terasa kian memudar dari bangunan kepribadian umat beragama. Sikap intoleransi yang dapat mengarah pada tindakan radikal dan bahkan kekerasan atas nama agama tak hentinya mengancam kemajemukan umat dan bangsa Indonesia hingga sekarang. ${ }^{10}$

Penelitian yang dilakukan oleh Puslitbang Pendidikan Agama dan Keagamaan menunjukkan bahwa potensi intoleransi memang ada dalam komunitas sekolah dan Madrasah. Data penelitian memperlihatkan bahwa potensi intoleransi keagamaan dikalangan siswa sekolah berkisar antara $17-27 \%$, tergantung pada isu-isu yang dipertanyakan pada siswa. ${ }^{11}$ Demikian juga hasil penelitian yang diselenggarakan oleh Pusat

Kristen, maka pengalaman ini telah memperlebar jarak sosial antara komunitas Islam denganKristen. Jarak sosial ini akan mempersubur tumbuhnya sikap dan prilaku intoleransi antar penganut Islam dan Kristen yang dalam kondisi tertentu dapat melahirkan konflik keagamaan.

${ }^{8}$ Agus wibowo. 2012. Pendidikan Karakter - Strategi Membangun Karakter Bangsa Berperadaban, Jakarta: Pustaka Pelajar, h. $1-24$.

${ }^{9}$ Mundzier Suparta. 2008. Islamic Multicultural Education. Jakarta: Al Ghazali, h. 55 - 58

${ }^{10}$ Mulyani A. Nurhadi. 2012. Proceeding International Symposium on The Strategic Role of Religious Education in The Development of Culture of Peace. Jakarta: Centre for Research and Development and Training Ministry of Religious Affairs

${ }^{11}$ LAKIP dalam Puslitbang Pendidikan Agama dan Keagamaan. 2012. Masalah Sosial Keagamaan Peserta Didik SLTA Pulau Jawa dan Sulawesi. Jakarta: Puslitbang Pendidikan Agama dan Keagamaan.
Pengembangan Islam dan Masyarakat (PPIM) di Jawa, memperlihatkan adanya data bahwa potensi intoleransi pada sekolah cukup tinggi. Dari sampel 500 guru agama Islam di Jawa terdapat sekitar $60 \%$ guru yang berpotensi radikal. $^{12}$ Lebih lanjut hasil penelitian yang dilakukan oleh Lembaga Kajian Islam dan Perdamaian (LAKIP) di Jabodetabek, menunjukkan bahwa potensi intoleransi pada guru agama juga relatif tinggi. ${ }^{13}$

Namun menurut Anik Farida, bahwa dewasa ini telah banyak lembaga pendidikan sekolah dan madrasah yang melakukan pendidikan toleransi keagamaan. Hanya saja intensitas masing-masing lembaga pendidikan dalam mengembangkan pendidikan toleransi keagamaan berbeda satu sama lain. ${ }^{14}$ Secara nasional pendidikan toleransi tidak ada standar khusus. Pendidikan toleransi diserahkan pada satuan pendidikan masing-masing. Pemerintah hanya memberikan rambu-rambu yang tertuang dalam peraturan perundangan, seperti UndangUndang Nomor 20 Tentang Sisdiknas tahun 2003 dan Peraturan Pemerintah Nomor 19 Tentang Standar Nasional Pendidikan tahun 2005, serta Peraturan Pemerintah Nomor 55 Tentang Pendidikan Agama dan Keagamaan tahun 2007.

Tulisan ini menyajikan model pendidikan toleransikeagamaan padaSMA Muhammadiyah di Kupang. Identitas keagamaan para siswanya heterogen, terdiri dari Islam, Katolik dan Kristen. Kondisi ini dapat dipahami, karena memang mayoritas penduduk kota Kupang adalah Katolik dan Kristen. Gambaran identitas keagamaan siswa secara lengkap sebagaimana tabel berikut.

${ }^{12}$ Direktorat Pendidikan Agama Islam Pada Sekolah dan Pusat Pengkajian Islam dan Masyarakat(PPIM) UIN Jakarta. 2010. Survey Sikap Sosial-Keagamaan Guru Agama Islam Pada Sekolah Umum di Jawa. Jakarta: Direktorat Pendidikan Agama Islam Pada Sekolah. Ditjen Pendidikan Islam.

${ }^{13}$ Dikutip dari laporan Tim Peneliti Puslitbang Pendidikan Agama dan Keagamaan. 2011. Studi Paham Keagamaan di Sekolah Menengah Atas dan Madrasah Aliyah, Jakarta: Puslitbang Pendidikan Agama dan Keagamaan.

${ }^{14}$ Anik Farida et.all . 2010. Pendidikan Multikulturalisme Di Sekolah Menengah Atas. Jakarta: Kedeputian Bidang Pengembangan SIPTEKNAS Kementerian Riset dan Teknologi. 
Tabel 1. Jumlah Perbandingan Siswa Menurut Identitas Keagamaan di SMA Kupang Tahun 2011

\begin{tabular}{|l|l|l|l|}
\hline No & Identitas siswa & Frekuensi & $\%$ \\
\hline 1 & Islam & 121 & 39,54 \\
\hline 2 & Kristen & 89 & 29.08 \\
\hline 3 & Katolik & 96 & 31.38 \\
\hline & Total & 306 & 100.00 \\
\hline
\end{tabular}

Sumber: Data dokumentasi SMA Kupang 2011

Sebagai pembanding, kondisi identitas keagamaan sebaliknya terjadi pada sebagian sekolah Katolik di Blitar Jawa Timur. Menurut data yang dihimpun dari Kementerian Agama Kota Blitartahun 2012,terdapatbeberapa sekolah Katolik yang memiliki jumlah siswa Muslim lebih besar dari sekolah Katolik, di antaranya Sekolah Menengah Atas Katolik Diponegoro dan Sekolah Menengah Kejuruan Katolik Santo Yusuf. Kondisi ini juga bisa dipahami karena mayoritas masyarakat Blitar beragama Islam, dan masyarakat Islam menilai sekolah-sekolah Katolik tersebut termasuk kategori baik. ${ }^{15}$ Data identitas keagamaan siswa pada sekolah Katolik di Blitar sebagaimana tabel berikut.

Tabel 2. Data Identitas Keagamaan Siswa di Sekolah-sekolah Katolik Kota Blitar Tahun 2013

\begin{tabular}{|l|l|l|l|l|l|l|l|}
\hline Sekolah & Islam & $\begin{array}{l}\text { Kris- } \\
\text { ten }\end{array}$ & $\begin{array}{l}\text { Kato- } \\
\text { lik }\end{array}$ & Hindu & Budha & $\begin{array}{l}\text { Kong- } \\
\text { hucu }\end{array}$ & Iml \\
\hline $\begin{array}{l}\text { SDK Santa } \\
\text { Maria }\end{array}$ & 24 & 211 & 314 & 5 & 19 & 11 & 582 \\
\hline $\begin{array}{l}\text { SDK Yos } \\
\text { Sudarso }\end{array}$ & 21 & 89 & 95 & 1 & 2 & - & 208 \\
\hline $\begin{array}{l}\text { SMPK Yos } \\
\text { Sudarso }\end{array}$ & 41 & 106 & 99 & 6 & - & 1 & 253 \\
\hline $\begin{array}{l}\text { SMPK } \\
\text { Yohanes } \\
\text { Gabriel }\end{array}$ & 57 & 12 & 7 & - & - & - & 76 \\
\hline $\begin{array}{l}\text { SMAK } \\
\text { Diponegoro }\end{array}$ & 533 & 138 & 136 & 3 & 5 & 1 & 816 \\
\hline $\begin{array}{l}\text { SMKK } \\
\text { Santo } \\
\text { Yusuf }\end{array}$ & 1092 & 66 & 62 & 2 & 11 & - & 1233 \\
\hline Total & 1768 & 622 & 713 & 17 & 37 & 13 & 3168 \\
\hline
\end{tabular}

Sumber data: Dokumen Kementertian Agama Kota Blitar, 2013 2013

${ }^{15}$ Data Observasi dan wawancara lapangan, April
Pertanyaan umum penelitian adalah bagaimana SMA Muhammadiyah Kupang mengembangkan pendidikan toleransi keagamaan terhadap para siswanya? Secara khusus tujuan dari penelitian ini akan: 1) menjawab pertanyaan, apakah motivasi SMA Muhammadiyah Kupang mengajarkan pendidikan agama kepada para siswa non Muslim; 2) menggambarkan bagaimana pendekatan, stategi dan tehnik implementasi pendidikan toleransi yang berlangsung; 3) menggambarkan bagaimana pemahaman budaya toleransi para siswa SMA Muhammadiyah Kupang.

Atas dasar pertanyaan tersebut penelitian bertujuan untuk menggambarkan implementasi pendidikan toleransi keagamaan pada SMK Muhammadiyah di Kupang Nusatenggara Timur. ${ }^{16}$ Hasil penelitian ini dapat berguna untuk: 1) memberikan informasi tentang implementasi pendidikan agama SMA Muhammadiyah Kupang 2) memberikan contoh model pendidikan toleransi di lingkungan sekolah.

\section{METODOLOGI}

Penelitian ini bersifat studi kasus, dan dilakukan pada tahun 2011, dengan lokasi penelitian di SMA Muhammadiyah ${ }^{17}$ Kupang Nusatenggara Timur. Sebagaimana umumnya

${ }^{16}$ Kupang adalah kotamadya dan sekaligus ibu kota provinsi Nusa Tenggara Timur, sebuah kota terbesar di pesisir Teluk Kupang. Luas wilayah $180,27 \mathrm{~km}^{2}$ dengan penduduk sekitar 350.000 jiwa, dengan agama dan suku bangsa yang majemuk. Suku-suku bangsa yang ada di Kota Kupang adalah suku asli Timor, Rote, Flores dan sedikit suku pendatang seperti Tionghoa, Jawa dan Sulawesi. Kemajemukan agama dan suku bangsa ini telah lama berada, dan mereka telah lama hidup berdampingan secara harmoni. Kondisi sosial ini belakangan menjadi rentan terhadap konflik sosial keagamaan antara sukusuku asli dan suku pendatang, terutama karena adanya isu kesenjangan sosial ekonomi dan paham keagamaan yang berbeda antara mayoritas penduduk asli dan minoritas pendatang.

${ }^{17}$ Muhammadiyah dikenal sebagai organisasi Islam yang besar di Indonesia. Visi Muhammadiyah adalah sebagai gerakan Islam yang berlandaskan al Quran dan Dasar misinya adalah al Quran as Sunnah dengan watak tajdid dan aktif dalam melaksanakan amar ma'ruf nahi 
studi kasus, analisis penelitian ini bersifat deskriptif analitik terbatas pada kasus khusus. ${ }^{18}$ Dalam konteks ini analisis akan menjelaskan berbagai fenomena kegiatan sekolah dan maknanya terhadap pendidikan toleransi, khusus pada SMA Muhammadiyah Kupang. Uraian tentang tantangan pendidikan toleransi di sekolah secara umum, dan konsepkonsep toleransi secara makro merupakan bagian yang mendasari analisis pendidikan toleransi ini.

Kota Kupang memiliki lembaga pendidikan milik pemerintah dan swasta yang heterogin, sebagaimana tabel berikut.

Tabel 3. Jumlah Lembaga Pendidikan Di Kota Kupang Tahun 2011

\begin{tabular}{|l|l|l|}
\hline No & Lembaga Pendidikan & Jumlah \\
\hline 1 & TK & 94 \\
\hline 2 & SD/MI) & 121 \\
\hline 3 & SMP/MTs & 39 \\
\hline 4 & SMA/MA & 22 \\
\hline 5 & SMK & 17 \\
\hline 6 & Perguruan Tinggi & 21 \\
\hline & Total & 314 \\
\hline
\end{tabular}

Populasi siswa SMA Muhammadiyah Kupang sebagaimana tergambar pada tabel 1 sebanyak 306 orang, sedangkan jumlah guru sebanyak 27 orang. Informan utama dalam penelitian adalah pimpinan sekolah dan guru agama. Informan tersebut dipilih untuk mencari informasi tentang pelaksanaan pendidikan agama, kondisi sekolah, motif, pendekatan, model dan strategi pendidikan toleransi. Sedangkan sebagai responden untuk mengetahui pemahaman siswa tentang toleransi dipilih beberapa siswa Muslim dan beberapa siswa Kristen. Pemilihan para siswa tersebut dilakukan secara acak, dengan

munkar disegala bidang. (www.muhammadiyah.or.id), 2013.

${ }^{18}$ Sari Wahyuni. 2012. Qualitative Research Method - Theory and Practice. Jakarta: Penerbit Salemba empat. Hlm. 10 accidental sampling. Dalam hal ini, ketika peneliti mengunjungi sekolah, peneliti secara spontan mencari 5 orang siswa muslim dan 5 orang siswa Kristen untuk diminta mengisi kuesioner yang sudah disiapkan sebelumnya. Selain itu peneliti juga melakukan pengamatan langsung terhadap keberadaan ruang dan kantor sekolah dan mengamati para siswa yang sedang berkumpul/bermain ketika waktu istirahat sekolah. Jumlah data siswa dan guru diambil dari dokumen sekolah, sedangkan data informasi yang terkait dengan geografi, demografi dan Pendidikan secara umum Kota Kupang serta konsep toleransi dan tantangan pendidikan toleransi di ambil dari publikasi media cetak dan elektronik.

\section{KONSEP TOLERANSI}

Secara Etimologi, toleransi adalah kesabaran, ketahanan emosional, dan kelapangan dada. Menurut istilah, toleransi berarti bersikap menenggang(menghargai, membiarkan, membolehkan) pendirian (pendapat pandangan, kepercayaan, kebiasaan $\mathrm{dsb}$ ) yang berbeda dan atau yang bertentangan dengan pendiriannya. Budaya toleransi dalam konteks ini adalah adanya pikiran, sikap, prilaku, tindakan untukbersabar, menahan diri, menghargai, menghormati, tidak mengganggu atau melecehkan pihak lain, meskipun mereka berbeda faham, pandangandan keyakinan agamanya. ${ }^{19}$ Dalam konteks sosial, toleransi juga bermakna menyerahkan segala persoalan terhadap hukum yang berlaku dan tidak main hakim sendiri.

Dari aspek historis, konsep toleransi dalam Islam telah berkembang sejak masa Nabi Muhammad diangkat menjadi rasul sekitar tahun 610 M. Pada waktu itu antara Nabi Muhammad dan Waraqa bin Naufal, tokoh Nasrani, telah menjalin persahabatan yang harmoni melalui berbagai dialog keagamaan, yang saling mengakui kebenaran keyakinan masing-masing dan menghormati keyakinan sahabatnya. Peristiwa lain, ketika Raja Najasy

${ }^{19}$ Imam Tholkhah. 2010. Ahlak Pendidikan Islam. Jakarta: Titian Pena, h. 116-121 
dari Ethiopia meninggal dunia, Nabi meminta para sahabat untuk menyembahyangkan, pada hal belum ada kejelasan apakah Raja Najasy itu seorang muslim atau bukan. Peristiwa lain lagi, ketika Nabi melakukan dialog dengan utusan dari Najran yang beragama Kristen di Masjid Madinah dan kemudian delegasi itu memohon izin untukkebaktian di luar masjid, Nabi menyarankan agar delegasi tersebut melakukan kebaktian di dalam Masjid. ${ }^{20}$

Data historis masa Nabi yang terkenal dengan toleransi tercatat dalam Piagam Madinah. Di antara isinya adalah bahwa orang Muslim dan orang Yahudi mempunyai hak yang sama untuk saling tolong menolong dan mempertahankan agamanya. Bahkan ketika pembebasan Mekkah pada tahun 630 M oleh kaum Muslimin, Nabi melindungi kaum Nasrani di Makkah agar mereka tetap menganut agamanya dan beribadah sesuai dengan agamanya. Demikian juga ketika kaum Muslimin menguasai Yerussalem, Khalifah Umar menandatangani perjanjian yang di antara isinya adalah Khalifah akan menjamin jiwa, harta, gereja dan salib mereka untuk dipelihara. Umat Kristen diberikan hak untuk tetap memeluk agamanya dan keselamatan mereka mendapatkan jaminan. ${ }^{21}$

Dari sisi ajaran normatif, konsep toleransi yang ditawarkan dalam pendidikanIslamadalah bahwa setiap penganut agama harus meyakini kebenaran agamanya, tetapi dalam waktu yang bersamaan juga harus membiarkan atau menghormati penganut agama lain meyakini kebenaran agamanya. $^{22}$ Menjadi seorang yang toleran berarti menerima kehadiran keyakinan yang berbeda dan mengakui hak para pemeluknya, sementara pada saat yang

${ }^{20}$ Muhamad Malik. 2002. "Pluralisme Agama dan Toleransi Dalam Islam," Dialog - Jurnal Penelitian dan Informasi Keagamaan, No 54 Th.XXV, Desember.

${ }^{21}$ Imam Tholkhah. 2010. Ahlak dan Pendidikan Islam. Jakarta: Titian Pena. h.116-121.

${ }^{22} \mathrm{Abd}$.Fatah Wibisono. dkk. 2010. Islam Rahmatan Lil Alamiin- Buku Rujukan Guru PAI Sekolah Menengah Pertama (SMP).Jakarta: Direktorat Pendidikan Agama Islam, sama ia menolak isi ajaran agama tersebut. ${ }^{23}$ Pendidikan Islam mengajarkan bahwa tidak ada paksaan bagi seseorang untuk menganut agama ( al Baqoroh, 2 : 256). Pendidikan Islam juga mengajarkan bahwa kemajemukan bangsa merupakan sunnatullah yang tidak bisa di hindari. Rujukannya al Quran surat al Hujurat, 49: 13. Ayat tersebut menyiratkan bahwa ajaran Islam mengakui adanya keragaman yang meliputi suku bangsa, bahasa, budaya dan agama. Semua keragaman ini memiliki asal usul yang sama dan memiliki tujuan hidup yang sama yaitu menjadi individu yang mulia di sisi Tuhan. $^{24}$ Salah satu makna penting adanya keanekaragaman dalam ciptaan Allah ini bukanlah untuk mendorong pertentangan dan perang, melainkan agar manusia saling kenal mengenal.

Pendidikan Islam di sekolah umumnya mengajarkan perlunya sikap bertoleransi terhadap sesama manusia yang memeluk agama non Islam. Ayat al Quran yang menjadi rujukan adalah Surat al Maidah, $5: 48$. Ayat ini menjelaskan bahwa, setiap umat memiliki aturan dan jalannya sendiri, dan setiap umat harus yakin terhadap ajaran agamanya sendiri, karena Allah pasti akan menguji atas apa yang telah Ia berikan. Setiap umat beragama harus berlomba-loma dalam kebajikan. Setiap umat beragama harus menghormati perbedaan yang memisahkan mereka. Tidak di anjurkan bagi penganut agama untuk menghakimi keyakinan penganut agama lain, karena di hari akhir nanti, Allah akan menunjukkan apa yang diperselisihkan. ${ }^{25}$

\section{Tantangan Pendidikan Toleransi di Sekolah}

Implementasi pendidikan toleransi di sekolah umumnya menghadapi tantangan yang tidak ringan, karena komunitas sekolah

${ }^{23}$ Fuad Fachrudin. 2006. Agama dan Pendidikan Demokrasi: Pengalaman Muhammadiyah dan Nahdlatul Ulama. Jakarta: Pustaka Alfabet. h. 127

${ }^{24} \mathrm{Ibid}$.

${ }^{25}$ Hanief Saha Ghafur dkk. 2010. Islam Rahmatan Lil 'alamiin, Buku Rujukan Guru PAI Sekolah Dasar (SD). Jakarta: Direktorat Pendidikan Agama Islam . 
tidak steril dari berbagai pengaruh negatif dari adanya kelompok intoleran ${ }^{26}$ dan konflik keagamaan di luar sekolah. Sejarah menunjukkan bahwa konflik keagamaan di luar sekolah telah terjadi sejak lama. ${ }^{27}$ Pengalaman konflik keagamaan, khususnya antar umat Islam dan Kristen di Indonesia, misalnya di Maluku Utara, telah banyak memakan korban, termasuk hancurnya berbagai objek ritual keagamaan gereja dan masjid. ${ }^{28}$ Konflik keagamaan di suatu daerah meningkat lebih besar jika benturan antara kedua kelompok penganut agama yang berbeda memperoleh dukungan yang meluas dari kelompok keagamaan radikal-intoleran dari luar daerah. Secara empirik banyak faktor yang dapat melahirkan kelompok intoleran dan konflik keagamaan di Indonesia (yang ikut mempengaruhi komunitas sekolah), yakni faktor pemahaman agama, sosial, budaya, politik dan ekonomi. ${ }^{29}$ Berbagai faktor tersebut dapat dilihat dari sudut faktor internal, eksternal dan hubungan sosial. ${ }^{30}$

Faktor internal yang menjadi sebab sikap intoleran adalah: Pertama, adanya pemahaman agama yang sempit, dalam arti pemahaman yang mengarah pada fanatisme agama berlebihan. Fanatisme agama semacam ini dapat melahirkan sikap-sikap penolakan terhadap keberagamaan orang lain dan bahkan penolakan berinteraksi dengan pemeluk agama lain. Intoleransi keagamaan merupakan wujud nyata dari sikap penolakan tersebut. Kedua, adanya formalisme pandangan dan sikap keagamaan yang kaku. Formalisme agama lahir karena pandangan keagamaan

${ }^{26}$ Team Peneliti Puslitbang Pendidikan Agama dan Keagamaan. 2012. Masalah Sosial Keagamaan Peserta Didik SLTA Pulau Jawa dan Sulawsi. Jakarta: Puslitbang Pendidikan Agama dan Keagamaan. h. 3-4.

${ }^{27}$ Bahrul Hayat. 2012. Mengelola Kemajemukan Umat Beragama. Jakarta: Saadah Cipta Mandiri, h. 47 - 55

${ }^{28}$ Mantri Karno Diharjo, Sumber-sumber Konflik Di Maluku Utara (1999-2004), Mantrikarno's Weblog.

${ }^{29}$ Tim Peneliti Balai Litbang Agama Jakarta. 2011. Kasus Aktual Kehidupan Agama, Studi Pencegahan Dini Konflik Umat Beragama. Jakarta: Balai Litbang Agama Jakarta.

${ }^{30}$ Bahrul Hayat. 2012. Mengelola Kemajemukan Umat Beragama. Jakarta: Saadah Cipta Mandiri. yang tidak inklusif. Formalisme agama lebih mementingkan simbol-simbol agama formal dari pada substansi ajarannya, sehingga dapat melahirkan sikap-sikap keberagamaan yang eksklusif, membuat jarak sosial yang lebar dengan para penganut faham keagamaan yang berbeda. Ketiga, adanya aliran-aliran sempalan agama yang dinilai menodai eksistensi agama mayoritas. Keberadaan kelompok aliran agama dapat menjadi ancaman keharmonisan kehidupan beragama manakala paham agama digunakan untuk kepentingan-kepentingan politik. Selain itu faktor internal lingkungan sekolah juga dapat mempengaruhi lahirnya sikap intoleransi keagamaan siswa. Misalnya terbatasnya waktu pembelajaran agama, kualitas guru yang belum memadai, kualitas sarana pendidikan yang kurang, kurikulum pembelajaran agama yang belum mendukung, dan kurangnya kegiatan sekolah yang mendukung pendidikan toleransi.

Faktor eksternal yang ikut mempengaruhi munculnya konflik, disharmoni dan intoleransi antar kelompok penganut agama adalah adanya benturan kepentingan antar negara. Persaingan antar kelompok negara telah melahirkan hegemoni tingkat global yang pada gilirannya melahirkan perasaan tidak adil, tertindas bagi kelompok tertentu dalam negara yang lemah. Sebagian kelompok dalam negara yang merasa tertindas dan terdzalimi kemudian mengorganisasikan kekuatan dan melakukan perlawanan dengan kekerasan dalam bentuk teror-teror, sebagaimana terjadi pada negara Afganistan, Palestina, Irak, Filipina, Thailand, India, Myanmar dan Indonesia. Adanya gerakan radikal, intoleran dan teror beberapa tahun terakhir di Indonesia juga terkait dengan adanya solidaritas keagamaan global untuk melawan terhadap kekuatan hegemoni global oleh negara tertentu. ${ }^{31} \quad$ Faktor eksternal lain yang sering menjadi penyebab sikap intoleransi

${ }^{31}$ Kasus-kasus terorisme di Indonesia seperti pengeboman bunuh diri di Bali, di Jakarta, di Cirebon dan penggerebekan pelaku-pelaku teror akhir-akhir ini mereka adalah anggota kelompok radikal yang menyatakan menentang Amereka dan antek-antek Amerika di Indonesia. 
keagamaan menurut Mudzhar adalah karena adanya perasaan terganggu, terpinggirkan diperlakukan tidak adil oleh kepentingan kelompok agama lain. Di antara kepentingan tersebut dalah: 1) kelangsungan hidup suatu kelompok keagamaan merasa terancam, 2) kepentingan ekonomi kelompok agama merasa terancam, 3) status dan peran kelompok merasa terancam, 5) kepentingan ideologi kelompok merasa terancam. ${ }^{32}$ Aspek lain yang secara tidak langsung ikut mempengaruhi komunitas siswa sekolah adalah adanya budaya kekerasan yang ditampilkan melalui media cetak dan elektronik di dalam dan luar negeri, dakwah agama yang bersifat radikal dan adanya pengaruh keluarga yang tidak harmonis. Selain itu adanya pertemanan yang mengajak masuk dalam kelompok radikal serta adanya provokasi melalui media elektronik, radio, television dan hand phone.

Faktor hubungan sosial yang tidak harmonis sering menjadi pendorong sikap intoleransi keagamaan. Faktor hubungan sosial yang tidak harmonis antara kelompok umat beragama dapat melahirkan sikap intoleransi keagamaan. Hubungan yang tidak harmonis tersebut terjadi manakala salah satu atau lebih aktivitas penganut agama yang satu mengganggu atau mengancam eksistensi penganut agama lain. Beberapa faktor hubungan sosial yang sering menjadi pemicu konflik adalah:

Pertama: Benturan misi penyiaran agama. Kegiatan penyiaran agama baik secara lisan atau melalui media cetak, elektronik, dan pendidikan ${ }^{33}$ yang bersifat agresif atau provokatif, melecehkan, merendahkan dan menyinggung penganut agama lain dapat melahirkan konflik. Kalau penyiaran agama

${ }^{32}$ Mudzhar, 2005, dalam Bahrul Hayat. 2013. Mengelola, Kemajemukan Umat Beragama, Jakarta: Saadah Cipta Mandiri, h. 120

${ }^{33}$ Dewasa ini masih terdapat banyak lembaga pendidikan swasta yang tidak mengajarkan pendidikan agama sesuai dengan agama siswa. Kenyataan ini bertentangan dengan UU No 20 Tahun 2003 Tentang Sisdiknas. Kondisi ini ibarat menanam bom waktu, yang pada saatnya akan dapat meledakkan konflik antar umat beragama. sudah dirasakan telah mengancam eksistensi identitas penganut agama lain maka reaksi balik penentangan yang kuat akan terjadi.

Kedua, pendirian rumah ibadah. Setiap agamamemerlukantempatibadahyangbersifat kolektif. Tempatibadah melambangkanadanya penganut agama disekitar lokasi tempat ibadah tersebut. Namun lokasi pendirian tempat ibadah yang tidak tepat akan melahirkan konflik keagamaan. Pendirian tempat ibadah kelompok agama minoritas yang didirikan ditengah kelompok agama mayoritas sering memicu lahirnya konflik, yang berujung pada perusakan terhadap tempat ibadah tersebut.

Ketiga, perkawinan penganut beda agama. Konsekuensi masyarakat Indonesia yang majemuk telah melahirkan perkawinan antar penganut agama yang berbeda. Namun perkawinan semacam ini akan menjadi sumber konflik manakala dilakukan secara tidak normal. Misalnya perkawinan tidak memperoleh restu dari orang tuanya, kemudian orangtua atau keluarga yang tidak setuju melakukan propokasi untuk melakukan kekerasan terhadap pihak lain. Isu perkawinan beda agama yang tidak normal dapat menjadi isu pemurtadan agama.

Keempat, penodaan agama. Penodaan agama terjadi manakala penganut agama tertentu baik sengaja atau tidak sengaja melakukan kegiatan atau berprilaku yang dipandang melecehkan penganut agama lain. Misalnya memaki, menginjak, merobek, mengotori simbol-simbol penganut agama lain yang dipandang suci.

Kelima, penyelenggaraan hari besar agama yang tidak kondusif dengan masyarakat lingkungannya. Setiap agama memiliki hari besar yang selalu dirayakan oleh penganutnya. Tetapi perayaan hari besar agama yang berlebihan, yang mengganggu mayoritas lingkungan penganut agama lain, dapat menimbulkan ketegangan dan konflik keagamaan.

Keenam, perpindahan penduduk. Tradisi migrasi penduduk Indonesia dari satu daerah ke 
daerah lain, baik melalui program transmigrasi pemerintah atau mandiri sudah berjalan sejak masa lalu. Perpindahan penduduk pendatang pada umumnya disertai dengan perpindahan agama dan budaya. Kehadiran pendatang pada suatu wilayah yang kebetulan memiliki latar belakang agama dan budaya yang berbeda dengan penduduk asli seringkali akan melahirkan konflik keagamaan. Konflik keagamaan ini muncul jika dalam proses perjalanannya melahirkan kecemburuan sosial ekonomi dan politik dari penduduk asli pada pendatang. Kecemburuan sosial, ekonomi dan politik terjadi karena kelompok pendatang menguasai sektor-sektor ekonomi dan kekuasaan publik, sedangkan penduduk asli tetap dalam kondisi termarjinalkan dan miskin .

Dalam menghadapi berbagai tantangan munculnya konflik keagamaan dan lahirnya sikap-sikap intoleransi keagamaan, apapun faktornya seringkali melibatkan komunitas pemuda dan pelajar. Menghadapi fenomena tersebut, pendidikan toleransi keagamaan di sekolah menjadi penting agar para siswa dapat menegakkan nilai-nilai toleransi. Setiap pendidikan agama mengajarkan nilai toleransi seperti ajaran kasih sayang, saling tolong menolong antar sesama manusia, dan cinta akan perdamaian. Dalam realita, nilainilai ajaran agama tentang toleransi tersebut belum sepenuhnya dapat diimplementasikan dalam kehidupan sehari-hari. Perbedaan agama justru sering dijadikan alat untuk mengesahkan terjadinya tindak kekerasan keagamaan. ${ }^{34}$ Oleh karena itu, pendidikan toleransi keagamaan di sekolah perlu terus dikembangkan. agar masalah pertentangan agama dapat di hindari di masa yang akan datang.

Secara substansial, kepedulian dunia sekolah terhadap pendidikan toleransi mulai dari pendidikan anak usia dini hingga menengah atas telah dilakukan. Tujuannya adalah agar anak Indonesia sejak usia dini

${ }^{34}$ Amin Abdullah. 2005. "Pengantar" Dalam M Ainul Yakin. Pendidikan Multikultural Cross-Cultural Understanding untuk Demokrasi dan Keadilan. Jakarta: Pilar. dibiasakan memiliki karakter yang baik, sikap saling menghargai, menghormati, tolong menolong, bekerjasama antar sesama, meskipun mereka berbeda agama, suku bangsa, bahasa ibu, dan tingkat ekonomi. Bagi komunitas sekolah, substansi pengembangan budaya toleransi dapat dinilai sebagai bagian dari pendidikan karakter. Karena itu pendidikan toleransi tidak bertentangan dengan tujuan pendidikan nasional dan pendidikan agama di sekolah. Bahkan pendidikan toleransi merupakan bagian yang tak terpisahkan dari tujuan pendidikan agama itu sendiri, khususnya untuk memperkokoh pembentukan ahlak mulia para siswa dalam membangun karakter bangsa.

\section{HASIL DAN PEMBAHASAN}

\section{Motif Pendidikan Toleransi SMA Muhammadiyah}

Muhammadiyah merupakan organisasi Islam modern yang sangat peduli terhadap lembaga pendidikan sekolah. Melalui jaringan anggotanya yang tersebar di berbagai pelosok tanah air, Muhammadiyah telah banyak mendirikan lembaga pendidikan mulai tingkat anak usia dini hingga perguruan tinggi yang tersebar di berbagai daerah. Motivasinya adalah dakwah agama Islam melalui lembaga pendidikan. Di antara sekolah Muhammadiyah yang dibangun berlokasi di Kupang Nusa Tenggara Timur, yang sebagian besar siswanya adalah non Muslim. Menghadapi kondisi sosial semacam itu kebijakan SMA Muhammadiyah Kupang adalah mendidik siswa sebagai upaya untuk mencerdaskan anak bangsa tanpa harus menukar keyakinan agamanya.. ${ }^{35}$ Kondisi semacam ini sesuai dengan hasil studi Abdul Mu'thi dan Fajar Riza ul Haq pada sekolah Muhammadiyah di daerah mayoritas Kristen seperti di Ende, Flores (NTT) dan Seruni Papua). Di kedua daerah tersebut sekolah Muhammadiyah menerima siswa Kristen dan diberikan pendidikan agama Kristen oleh

${ }^{35}$ Wawancara, guru agama Islam SMA Muhammadiyah Kupang, 2011 
guru agama Kristen. Dalam kaitan ini, Uskup Agung (emeritus) Ende, Mgr Donatus Djagom turut merespon positif SMA Muhammadiyah setempat, bahkan memberikan sumbangan untuk pengembangannya. ${ }^{36}$

Kebijakan ini berfungsi sebagai adaptasi sosial untuk upaya mempertahankan kelangsungan lembaga pendidikannya. Adaptasi sosial ini selaras dengan tuntutan Undang-Undang Nomor 20 Tahun 2003, pasal 12, dan Undang-Undang Nomor 23 Tahun 2002 Tentang Perlindungan Anak. Pimpinan SMA Muhammadiyah di Kupang mengikuti kebijakan organisasi Muhammadiyah, dan memandang hal tersebut juga selaras dengan ajaran agama Islam yang diyakininya. Selain itu SMA Muhammadiyah juga tidak mewajibkan memakai jilbab bagi para siswa yang nonMuslim. Dengan kebijakan tersebut para orangtua siswa non Muslim di Kupang tidak ragu-ragu untuk menyekolahkan anaknya di SMA Muhammadiyah.

Kebijakan SMA Muhammadiyah ini berbeda dengan kebijakan SMK Katolik di Blitar dan SMA Katolik di Batam. Pada kedua sekolah tersebut para siswa non Katolik tidak diajarkan pendidikan agama sesuai dengan agama siswanya. Seluruh siswa diberikan pendidikan agama Katolik. Dalam hal mata pelajaran agama di sekolah Katolik tersebut tidak ada toleransi. Semua siswa harus mengikuti pendidikan Katolik, meskipun aturan sekolah tersebut bertentangan dengan Undang-Undang Nomor 20 Tahun 2003 tentang Sisdiknas, pasal 12 dan tidak selaras dengan Undang-Undang Nomor 23 Tahun 2002 Tentang Perlindungan Anak. ${ }^{37}$

Salah satu alasan penting para siswa Kristen tertarik pada SMA Muhammadiyah, ialah karena SMA Muhammadiyah tidak mendorong murid Kristen pindah agama. SMA Muhammadiyah mengajarkan pendidikan agama Kristen kepada siswa Kristen oleh

${ }^{36}$ Abdul Mu'ti \& Fajar Riza Ul Haq, 2009. Kristen Muhammadiyah Konvergensi Muslim dan Kristen dalam Pendidikan, Jakarta: Al Wasat Publishing House

${ }^{37}$ Observasi lapangan dan wawancara dengan pimpinan sekolah Katolik di Blitar, April 2013, wawancara dengan kepala sekolah Katolik Batam, Juli, 2013. guru yang beragama Kristen. Selain itu SMA Muhammadiyah dinilai sekolah yang baik. Bagi siswa Kristen, dengan belajar di sekolah tersebut, mereka dapat memperoleh manfaat: 1) Memiliki akses yang luas untuk bersahabat dengan komunitas muslim; 2) Kualitas pendidikan sesuai standar nasional; 3) Memahami sebagian budaya komunitas dan ajaran Islam; 4) Kalau suatu saat mereka menjadi tokoh agama, pastor atau pendeta akan memungkinkan memiliki sikap yang moderat dan mampu berkomunikasi dengan para tokoh umat Islam.

Di sisi lain, para siswa Muslim di SMA Muhammadiyah juga memperoleh manfaat, karena mereka: 1) Memiliki akses pergaulan terhadap komunitas non-Muslim, sehingga mampu memahami pandangan budaya toleransi yang lebih baik. 2) Memahami budaya komunitas non Muslim yang bermanfaat dalam membangun persatuan bangsa. 3) Apabila suatu saat menjadi tokoh agama atau tokoh masyarakat, mereka memiliki pandangan keagamaan inklusif. Sebagaimana umumnya agama yang mengajarkan nilai inklusif, pendidikan agama di SMA Muhammadiyah hakikatnyajuga mengajarkannilaiinklusif,yang mendorong siswanya memiliki sikap moderat dan toleran. Selaras dengan nilai toleransi, ajaran agama di SMA Muhammadiyah sangat mendorong umatnya agar tampil humanis, santun dan terbuka kepada semua lapisan masyarakat. Karena itu tidak mengherankan apabila komunitas SMA Muhammadiyah Kupang, dapat bertemu dengan komunitas agama Kristen, sehingga mampu membangun kerjasama lintas agama yang harmonis. Itulah wajah SMA Muhammadiyah Kupang yang sedang menampilkan ajaran Islam rahmatan lil-alamain.

Implementasi pendidikan agama pada SMA Muhammadiyah sangat mengembangkan pendidikan toleransi yang khas. Praktik toleransi antara minoritas Islam dengan mayoritas Kristen dalam wadah pendidikan Muhammadiyah dapat dijadikan contoh oleh lembaga pendidikan sekolah yang lain. Dengan pendekatan adaptif semacam itu, SMA 
Muhammadiyah di Kupang dapat diterima dengan baik oleh masyarakat Katolik. Bahkan hampir 2/3 muridnya beragama Kristen/ Katolik. ${ }^{38}$ Fakta ini juga diharapkan mampu menggugah secara bersama, bahwa bumi nusantara ini memerlukan upaya konvergensi pendidikan dan hubungan sosial yang kokoh dalam menyongsong peradaban bangsa Indonesia ke depan yang makin beradab.

\section{Pendekatan dan Model Pengembangan}

Pendidikan toleransi di SMA Muhammadiyah Kupang dapat disebut sebagai pendekatan budaya, dalam arti menyesuaikan dengan budaya lingkungan sekolah, dengan menciptakan kondisi, wawasan, kesadaran dan iklim lingkungan pergaulan komunitas sekolah untuk bersikap toleran kepada sesama manusia. Pendekatan budaya dilakukan agar para siswa di sekolah terbiasa bersikap dan berprilaku toleran bukan karena terpaksa atau takut pada seseorang, tetapi karena adanya pikiran, kesadaran, dan kemauan sendiri untuk bersikap toleran. Sikap toleran dipandang oleh pimpinan sekolah sebagai bagian budaya luhur bangsa Indonesia, yang dipandang tidak bertentangan dengan ajaran Islam. Pandangan ini selaras dengan studi yang dilakukan oleh Fuad Fakhrudin tentang pandangan tokoh-tokoh Muhammadiyah tentang Toleransi. ${ }^{39}$ Dengan pendekatan semacam itu diharapkan para siswa setelah keluar dari SMA Muhammadiyah tidak mudah terpengaruh oleh adanya provokasi untuk berprilaku intoleran terhadap kelompok sosial yang berbeda agama tetapi justru sebaliknya diharapkan dapat menjadi pendorong untuk mengembangkan budaya toleransi pada komunitas di sekitarnya.

${ }^{38}$ Di berbagai tempat perguruan Muhammdiyah, yang pada awalnya dirintis oleh pendiri Muhammadiyah, Kyai Haji Ahmad Dahlan (pendiri organisasi Muhammadiyah) telah menyepakati untuk menyediakan guru Kristen atau Katolik kalau pada perguruan tersebut terdapat siswa Kristen (wawancara, kepala sekolah, April 2013).

${ }^{39}$ Fuad Fakhruddin. 2006. Agama dan Pendidikan Demokrasi: Pengalaman Muhammadiyah dan Nahdlatul Ulama. Jakarta: Pustaka Alvabet dan Yayasan INSEP.
Pembiasaan para siswa sekolah, untuk menjunjung tinggi nilai toleransi seperti berteman, menolong, menghargai dan menghormati para siswa yang berbeda faham keagamaan di apresiasi sebagai bagian dari pengamalan ajaran agama. Pembiasaan tersebut tidak hanya berlaku untuk komunitas siswa semata, tetapi juga komunitas pendidik dan tenaga kependidikan yang ada dalam lingkungan SMA Muhammadiyah Kupang. Pendidikan toleransi dengan pendekatan budaya dapat berjalan karena adanya dukungan dari seluruh unsur komunitas sekolah seperti guru, pengawas, kepala sekolah, komite sokolah, masyarakat lingkungan dan juga pemerintah di NTT

Pendekatan budaya dilakukan dengan simbol-simbol, fasilitas dan kegiatan keagamaan yang dapat di lihat, dirasakan dan di alami oleh segenap unsur komunitas sekolah sebagai bagian dari pendidikan toleransi. Simbol-simbol dan fasilitas keagamaan seperti adanya kitab suci dan buku-buku agama Kristen, serta gambar, pamplet, baliho, audio visual yang menggambarkan sikapsikap toleransi sebagai bagian penting dalam budaya toleransi telah dikembangkan di SMA Muhammadiyah Kupang. Demikian juga adanya kegiatan seperti belajar mengajar agama Kristen di sekolah serta dialog, kerjasama, workshop antar siswa atau guru lintas paham keagamaan yang dilaksanakan dengan saling menghargai merupakan bagian dari pendidikan toleransi.

Pada satu sisi, pendidikan toleransi di SMA Muhammadiyah dapat disebut sebagai model integratif, karena pengembangannya dilaksanakan secara menyatu melalui kegiatan intra dan extra kurikuler. Mata pelajaran agama diberikan oleh guru agama yang seagama dengan para siswanya. Materi agama yang diberikan di kelas mengajarkan dalil-dalil dan nilai-nilai agama sesuai dengan ajaran agamanya masing-masing. Dalam kegiatan extra kurikuler, Sekolah mengembangkan kegiatan bersama antara siswa muslim dan non muslim. Beberapa kegiatan bersama yang dilakukan adalah olahraga, studi tour, 
camping dan juga peringatan hari-hari besar nasional dan keagamaan. Kegiatan -kegiatan tersebut dapat dipandang sebagai bagian dari pendidikan toleransi di sekolah, karena telah membiasakan dan memperkaya pengalaman antar siswa yang berbeda agama untuk saling kerjasama, menghargai dan menghormati satu sama lain.

Pada sisi lain, pendidikan toleransi di SMA Muhammadiyah dapat di sebut sebagai model sinergis, karena kegiatan pendidikan toleransi di sekolah melibatkan berbagai unsur luar komunitas sekolah, yakni masyarakat sekitar sekolah yang berbeda agama. Beberapa kegiatan antara lain: 1) Menjalin kerjasama dengan komunitas/kelompok dari komunitas non Muslim di sekolah 2) Menerima guru-guru umum dan agama non Muslim untuk mengajar di SMA Muhammadiyah, meskipun jumlahnya masih terbatas. 3) Memberikan kesempatan dan memfasilitasi kegiatan keagamaan non muslim di lingkungan sekolah, misalnya perayaan Natal. 4) Memperlakukan siswa berbagai agama secara adil, tidak membedabedakan perlakuan dalam pendidikan. ; 6) Memberikan peluang dan kesempatan yang sama kepada setiap siswa untuk maju dan berkembang apapun agamanya;7) Memberikan kemudahan ibadah yang sama kepada setiap siswa yang berbeda agama.

\section{Strategi Pengembangan}

Atas dasar berbagai pengamatan, wawancara dan studi dokumentasi, strategi yang dilakukan antara lain:

Pertama, melalui pengembangan sekolah yang inklusif. Strategi ini ditunjukkan dengan adanya SMA Muhammadiyah telah menerima para siswa yang beragama Katolik dan Kristen dan mereka diberikan pelajaran agama sesuai dengan agamanya. Strategi ini dilakukan agar SMA Muhammadiyah fungsional terhadap masyarakat sekitar yang mayoritas beragama lebih Katolik dan Kristen. Karena itu, dengan strategi ini, bahwa SMA Muhammadiyah Kupang dapat diniai sebagai lembaga pendidikan yang inklusif dari segi faham keagamaan.

Kedua, melalui peningkatan wawasan keagamaanparaguruyanginklusif.Peningkatan wawasan ini di lakukan agar para guru makin professional dan memiliki kemampuan membentuk sikap serta prilaku siswa sesuai dengan ajaran agamanya yang berwatak toleran. Para guru terutama guru pendidikan agama SMA Muhammadiyah Kupang di tuntut memiliki profesionalitas yang lebih handal menghadapi heteroginitas keagamaan siswa. Dalam membentuk karakter siswa yang berbudaya toleransi, seluruh pendidik, terutama guru agama di tuntut memiliki keluasan pengetahuan agama agar mampu menjelaskan berbagai persoalan hubungan antar umat atau siswa yang berbeda agama. Selain itu para guru di SMA Muhammadiyah diharapkan tidak hanya mengajarkan ilmu pengetahuan tentang toleransi di dalam kelas, tetapi juga diharapkan mampu memberikan keteladanan dalam bersikap toleransi di luar kelas. Peningkatan wawasan guru yang inklusif dilakukan melalui diskusi, dan dialog dalam bentuk formal maupun informal dalam komunitas sekolah. Kepala sekolah, sebagai pimpinan satuan pendidikan, memberikan dukungan, inisiasi dan fasilitasi atas kegiatan-kegiatan yang memperluas wawasan keagamaan para guru yang inklusif.

Ketiga, melalui penanaman nilai toleransi sejak siswa masuk sekolah. Yakni dengan melakukan pembiasaan untuk membentuk sikap saling menghargai dan saling menghormati sesama siswa dalam komunitas sekolah. Selain itu karakter yang inklusif, menghargai perbedaan bagi para peserta didik yang berbeda agama terus dijaga hingga para siswa menyelesaikan pendidikan di SMA Muhammadiyah Kupang. Secara konseptual, strategi penanaman budaya toleransi sejak para siswa berada di sekolah memang terus dilakukan. Kenyataan ini dapat dipahami, karena pada masa sekolah pembentukan karakter anak memang bisa menjadi fondasi yang kokoh untuk membangun karakter anak ketika menjadi dewasa. Masa usia anak 
sekolah merupakan masa yang tepat untuk penanaman nilai-nilai toleransi, karena masa anak usia sekolah merupakan masa yang sangat rentan terhadap pengaruh nilai negatif dari lingkungan sosialnya. Mereka memperoleh benteng yang kuat dengan menanamkan nilai-nilai positif, seperti nilai toleransi dalam masyarakat Indonesia yang majmuk. Penanaman nilai toleransi sejak anak masuk sekolah tidak hanya berfungsi untuk mencegah konflik keagamaan dalam skala yang panjang, tetapi secara tidak langsung juga berfungsi untuk memperkokoh persatuan dan kesatuan bangsa, serta menciptakan perdamaian, perlindungan dan rasa aman pergaulan manusia sehari hari. Perlindungan dan rasa aman merupakan kebutuhan yang paling dasar manusia, selain makan, minum, tidur dan seks dalam hirarki kebutuhan dasar Abraham Maslow. ${ }^{40}$ Karena itu sikap dan prilaku toleransi yang dikembangkan sejak dini merupakan prasyarat untuk terpenuhinya kebutuhan dasar manusia dalam pergaulan, yakni menumbuhkan sikap dan prilaku yang bernilai kasih sayang, tolong menolong, kerjasama, hidup rukun, damai dan penghargaan terhadap perbedaan jenis kelamin, suku bangsa, warna kulit, pemikiran, budaya dan keyakinan keagamaan.

Keempat, melalui peningkatan akses pendidikan toleransi di sekolah. Akses pendidikan toleransi ini menurut tidak hanya ada pada guru, tetapi juga pada sumber belajar lain seperti sarana kepustakaan di sekolah. Sebagaimana disampaikan oleh kepala sekolah Muhammadiyah, kepustakaan di sekolah dikembangkan dengan menyediakan bacaan pendidikan agama yang yang mencakup bukubuku agama katolik dan buku-buku agama Kristen, di samping buku-buku apelajaran agama Islam. Selain itu, disediakan juga bukubuku pegangan guru dan siswa dan bukubuku referensi tentang pemikiran agama yang moderat, yang mendukung berkembangnya budaya toleransi. Bahkan sekolah juga menyediakan multi media, agar siswa terbiasa

\footnotetext{
${ }^{40}$ Imam Tholkhah. 2008. Manusia, Agama dan Perdamaian. Jakarta: Al Ghazali.
}

mengakses berbagai informasi ajaran agama yang lebih luas dan mendalam.

Kelima, melalui penguatan substansi kurikulum bernuansa toleransi. Kemunculan konflik sosial seringkali bermula dari keterbatasan budaya seseorang untuk menerimasesuatuyangberbedadengandirinya. Menyikapi persoalan ini, SMA Muhammadiyah Kupang, sebagaimana disampaikan oleh kepala sekolah telah mengembangkan pendidikan agama bernuansa toleransi yang menekankan agar para siswa tidak menjadikan setiap perbedaan faham sebagai ladang konflik, melainkan ladang berlomba dalam kebaikan . Istilah berlomba dalam kebaikan (fastabikul khoirot) dijadikan sebagai moto SMA Muhammadiyah Kupang. Program penguatan pendidikan toleransi dilakukan oleh guru-guru di sekolah dengan persetujuan kepala sekolah.

Keenam, melalui pemberdayaan organisasi siswa. Pemberdayaan organisasi siswa dilakukan dalam rangka mengikut sertakan para aktivis siswa untuk mengembangkan budaya toleran berbasis nilai agama. Tujuannya adalah agar para aktivis siswa merasa memiliki dan ikut bertanggungjawab serta mendukung proses pendidikan toleransi di sekolah. Pemberdayaan ini dinilai penting karena dari sudut sosiologis, kelompok organisasi siswa termasuk generasi muda kader pemimpin masyarakat yang perlu mendapat bekal untuk memahami nilai toleransi dalam kehidupan bangsa Indonesia yang majemuk. Pemberdayaan organisasi siswa juga ditingkatkan agar potensi toleransi yang berkembang di kalangan para siswa terus di jaga dan bahkan diperkuat oleh sesama siswa. Dari penelitian ini terlihat bahwa budaya toleransi para siswa di SMA Muhammadiyah sangat memadai, dengan indikator tingkat toleransi yang sangat tinggi, melebihi ratarata tingkat toleransi di berbagai daerah lain yang ditemukan oleh penelitian Puslitbang Pendidikan Agama dan Keagamaan. ${ }^{41}$ Pember-

${ }^{41}$ Penelitian Puslitbang Pendidikan Agama dan Keagamaan menunjukkan indikator potensi toleransi di daerah sample peneltitian adalah sebagai berikut: 1) Terdapat sekitar $83 \%$ siswa SLTA tidak setuju terhadap 
dayaan peran Organisasi siswa dalam hal tolelansi dilakukan melalui pengembangan program kegiatan dialog dan kerjasama sosial siswa lintas agama. Program kegiatan dialog dilakukan dalam bentuk diskusi, halaqoh, seminar. Sedangkan program kegiatan kerjasama siswa lintas agama dan lintas sekolah dapat dilakukan dalam bentuk kerja bakti, bantuan sosial pada korban bencana, panti anak yatim, panti jompo, dan sejenisnya dengan pengendalian dari guru-guru agama terkait.

Ketujuh, melalui pelibatan peran keluarga siswa. Pengembangan pendidikan toleransi di SMA Muhammadiyah tidak hanya tanggung jawab satuan pendidikan sekolah, tetapi juga lingkungan keluarga peserta didik masingmasing. Keluarga, khususnya kedua orang tua memiliki posisi yang paling penting dalam mengembangkan budaya toleransi. Dalam hal ini SMA Muhammadiyah memiliki hubungan yang baik dengan orang tua siswa, yakni dengan saling memberikan informasi tentang perkembangan siswa, meskipun frekuensinya tidak terlalu sering. Dalam kaitan ini guru agama, komite sekolah dan kepala sekolah memiliki peran strategis untuk mendorong orang tua siswa agar ikut serta mendukung pendidikan toleransi. Komunikasi dan dialog dua arah yang intensif dengan para orang tua siswa dilakukan. Orang tua mengetahui perkembangan hasil pendidikan anaknya di Sekolah, dan sebaliknya sekolah mengetahui perkembangan pengamalan ajaran agama di luar sekolah.

Kedelapan, melalui pelibatan peran masyarakat lingkungan sekolah. Pada SMA Muhammadiyah, Masyarakat lingkungan sekolah dilibatkan agar mereka ikut serta mengawasi prilaku para siswa yang sedang berada di luar sekolah, agar tidak melakukan

tindakan warga yang menolak pelaksanaan ibadah agama lain. 2) Terdapat $74 \%$ siswa SLTA tidak setuju terhadap tindakan warga yang menolak pembangunan rumah ibadah agama lain. 3) Terdapat sekitar $73 \%$ siswa SLTA yang tidak setuju terhadap tindakan warga yang merusak rumah/fasilitas milik anggota aliran keagamaan yang di anggap menyimpang. aktivitas yang menyimpang dari nilai-nilai ajaran agama, meskipun sifatnya diakui masih informal. Dalam hal ini komite sekolah, kepala sekolah, para guru, terutama guru agama memiliki peran penting untuk melakukan pendekatan dan dialog mengajak masyarakat sekitar sekolah untuk ikut mengawasi para siswa ketika berada di luar sekolah, untuk menciptakan pengamalan agama yang kondusif.

Kesembilan, melalui peningkatan hubungan dengan pemerintah. Kepala SMA Muhammadiyah merasakan bahwa pemerintah telah ikut berperan dalam mengembangkan sekolah ini melalui bantuan finansial terhadap kegiatan sekolah. Kedekatan hubungan sekolah dengan pemerintah ditandai adanya bantuan fasilitas dan bantuan dana pengembangan fisik gedung sekolah SMA Muhammadiyah.

\section{Pemahaman Siswa Tentang Nilai-Nilai Toleransi}

Secara umum dapat dikatakan bahwa siswa SMA Muhammadiyah Kupang memiliki telah wawasan tentang prinsip-prinsip toleransi. Dari sepuluh reponden siswa yang terpilih menjadi responden umumnya mengetahui dan sependapat dengan pernyataan: 1) Setiap agama menyetujui ide kebebasan untuk mengungkapkan pendapat dalam bentuk lisan dan tulisan, termasuk foto, gambar dan lain -lain. 2) Setiap agama memiliki kebebasan untuk tumbuh dan berkembang di Indonesia; 3) Ajaran setiap agama menyetujui ide kebebasan untuk mendirikan organisasi dan berserikat. Tidak seorangpun dari para siswa yang menjadi responden menolak atau tidak setuju dengan 3 pernyataan di atas.

Demikian juga ketika para siswa diminta pendapatnya HAM, dari sepuluh responden yang ditemui, secara keseluruhan telah memahami prinsip-prinsip HAM. Indikasinya adalah mereka semua sependapat dengan 4 pernyataan berikut: 1) Setiap agama melarang digunakannya cara-cara kekerasan untuk menyelesaikan persoalan, termasuk masalah perbedaan agama dan keyakinan; 
2); Setiap orang berhak untuk memilih dan mempertahankan keyakinannya; 3) Setiap agama mengajarkan bahwa semua manusia sama di hadapan Tuhan, yang membedakan hanya amalannya; 4) Setiap agama, suku, ras dan golongan memiliki kedudukan yang sama di mata hukum. Dari responden yang ditemui, tidak satu orang siswapun yang menolak terhadap pernyataan tersebut.

Mengenai pemahaman budaya toleransi keagamaan, nampaknya tidak ada masalah yang mengkhawatirkan. Dari sepuluh responden yang ditemui mereka menyetujui pernyataan berikut: 1) Setiap agama menghargai dan menghormati perbedaan agama dan keyakinan; 2) Agama mengajarkan umatnya untuk saling menghargai antar sesama pemeluk agama; 3) Setiap warga Negara memiliki hak dan kewajiban yang sama di mata hukum Indonesia; 4) Setiap agama menghargai perbedaan agama, suku ras dan golongan;

Tingginya sikap toleransi para siswa SMA Muhammadiyah di antaranya karena mereka telah memahami aturan dan prinsip-prinsip ajaran toleransi. Sebagaimana dinyatakan oleh kepala sekolah, dalam peraturan sekolah tidak ada perbedaan perlakuan antara siswa muslim dan siswa non muslim. Mereka samasama memperoleh hak untuk mendapatkan pendidikan agama sesuai dengan agamanya, dan mereka memperoleh pengajaran dari guru yang seagama. Para siswa berbeda agama dilibatkan dalam penyusunan berbagai peraturan yang terkait dengan organisasi siswa sekolah. Nilai toleransi juga dikembangkan melalui tradisi bahwa para siswa boleh menyampaikan kritiksecaralangsung terhadap pengurus organisasi siswa; Lebih jauh para siswa juga boleh menyampaikan kritik secara langsung terhadap pimpinan sekolah bila tidak puas dengan kinerjanya. Para siswa tidak dilarang menyampaikan paham agamanya di sekolah. Para siswa berbeda agama dapat melakukan kegiatan extra kurikuler sesuai dengan ajaran agamanya.

Dari sisi guru, pengembangan toleransi dikembangkan melalui kebersamaan dalam menyusun peraturan yang berlaku di sekolah. Dalam pertemuan, para guru juga dibolehkan menyampaikan pendapatnya secara langsung terhadap pimpinan sekolah bila tidak puas dengan kinerja dan kebijakannyanya. Pimpinan Sekolah tidak melarang para guru untuk menyampaikan pendapatnya tentang paham ajaran agamanya. Para guru tersebut berasal dari berbagai perguruan tinggi. Sebagian mereka berasal dari lingkungan dan pendidikan Universitas Cendana, Universitas Hasanuddin Makasar, Universitas Patimura Maluku, Universitas Muhammadiyah Kupang dan Surakarta.

Menurut para informan materi yang terkait dengan pembelajaran toleransi antara lain berhubungan dengan tema-tema seperti: 1) Hubungan Negara dan pemeluk agama; 2) Penghargaan terhadap kebebasan beragama dan berkeyakinan.; 3). Penghargaan terhadap perbedaan agama, suku, ras dan golongan; 4) Hak asasi manusia; 5) Kebebasan untuk mengungkapkan pendapat secara lisan maupun tulisan. 6) Nasionalisme Indonesia; 7) Kebebasan untuk mendirikan organisasi. 8).Anti-kekerasan dalam menyelesaikan persoalan, termasuk perbedaan agama dan keyakinan. 9).Kesetaraan peran laki-laki dan perempuan dalam rumah tangga maupun dalam kehidupan sosial; 10) Anti-kekerasan terhadap perempuan dalam rumah tangga; 12) Hak dan Kewajiban sebagai warga negara Indonesia.

\section{PENUTUP}

\section{Kesimpulan}

Motivasi SMA Muhammadiyah Kupang mengembangkan pendidikan toleransi tidak hanya karena dorongan material untuk mempertahankan existensi lembaga pendidikan agar tetap berkembang, tetapi juga menjalankan Misi pendidikan Muhammadiyah yang inklusive sesuai ajaran agama Islam yang diyakininya. Pendidikan toleransi yang dikembangkan sejalan dengan tuntutan Undang-Undang Dasar Tahun 1945, Undang- 
Undang Nomor 20 Tahun 2003 Tentang Sistem Pendidikan Nasional dan Undang-Undang Nomor 23 Tahun 2002 Tentang Perlindungan Anak.

Pendekatan pendidikan toleransi yang dilakukan adalah pendekatan budaya, menyesuaikan dengan budaya yang berkembang di Kupang NTT. Stategi yang dilakukan adalah dengan melakukan: 1) Penerimaan siswa dan guru non muslim. 2) Peningkatkan budaya para guru tentang nilai toleransi; 3) Penanaman nilai toleransi kepada siswa sejak awal masuk sekolah; 4) Peningkatan akses nilai toleransi bagi siswa dan guru melalui perluasan sumber belajar. 5) Penguatan substansi kurikulum tentang nilai toleransi baik dalam kelas maupun luar kelas. Sedangkan tehnik implementasi pendidikan toleransi berlangsung dengan melibatkan seluruh unsur sekolah, orang tua siswa, masyarakat sekitar dan pemerintah, sesuai dengan fungsinya masing-masing.

Tingkat pemahaman budaya toleransi para siswa di SMA Muhammadiyah Kupang secara umum relatif memadai, karena para siswa pada semua agama dapat saling menghormati, bekerjasama dan saling tolong menolong. Nilainilai toleransi seperti menghargai perbedaan, demokrasi, HAM, tidak hanya dipahami secara baik, tetapi juga diimplementasikan dalam kehidupan sehari-hari dalam lingkungan komunitas sekolah.

\section{SUMBER BACAAN}

Abdullah, Amin. 2005. "Pengantar" Dalam M Ainul Yakin. Pendidikan Multikultural Cross-Cultural Understanding untuk Demokrasi dan Keadilan. Jakarta: Pilar.

Azra, Azyumardi. 2011. "Radikalisme Keagamaan Dan Deradikalisasi" dalam Abdurrahman Mas'ud (ed), Kerukunan Umat Beragama dalam Sorotan: Refleksi dan Evaluasi 10 Tahun Kebijakan dan Program Pusat Kerukunan Umat Beragama. Jakarta: Pusat Kerukunan Umat Beragama, Sekretariat Jenderal Kemenag RI.
Fachrudin, Fuad. 2006. Agama dan Pendidikan Demokrasi: Pengalaman Muhammadiyah dan Nahdlatul Ulama. Jakarta: Pustaka Alfabet.

Farida, Anik, et.al. 2010. Pendidikan Multikulturalisme Di Sekolah Menengah Atas. Jakarta: Kedeputian Bidang Pengembangan SIPTEKNAS Kementerian Riset dan Teknologi.

Ghafur, Hanief Saha dkk. 2010. Islam Rahmatan Lil Alamiin- Buku Rujukan Guru PAI Sekolah Menengah Atas (SMK), Sekolah Menengah Kejuruan (SMK).Jakarta: Direktorat Pendidikan Agama Islam.

Ghafur, Hanief Saha dkk 2010. Islam Rahmatan Lil 'alamiin, Buku Rujukan Guru PAI Sekolah Dasar (SD). Jakarta: Direktorat Pendidikan Agama Islam .

Nafi, M. Dian. 2011. Simposium Nasional Pendidikan Agama dan Keagamaan. Jakarta: Puslitbang Pendidikan Agama dan Keagamaan.

Hayat, Bahrul. 2012. Mengelola Kemajemukan Umat Beragama. Jakarta: Saadah Cipta Mandiri.

Malik, Muhammad. 2002. "Pluralisme Agama dan Toleransi Dalam Islam," Dialog-Jurnal Penelitian dan Informasi Keagamaan, No 54 Th.XXV, Desember.

Mu'ti Abdul Mu'ti \& Fajar Riza Ul Haq, 2009. Kristen Muhammadiyah Konvergensi Muslim dan Kristen dalam Pendidikan, Jakarta: Al Wasat Publishing House

Mudzhar, Atho. 2005. Dalam Bahrul Hayat. 2013. Mengelola, Kemajemukan Umat Beragama, Jakarta: Saadah Cipta Mandiri.

Nurhadi, Mulyani A. 2012. Proceeding International Symposium on The Strategic Role of Religious Education in The Development of Culture of Peace. Jakarta: Centre for Research and Development and Training Ministry of Religious Affairs

Suparta, Mundzier. 2008. Islamic Multicultural Education. Jakarta: Al Ghazali. 
Tim Peneliti Pusat Pengkajian Islam dan Masyarakat(PPIM) UIN Jakarta. 2010. Survey Sikap Sosial-Keagamaan Guru Agama Islam Pada Sekolah Umum di Jawa. Jakarta: Direktorat Pendidikan Agama Islam Pada Sekolah. Ditjen Pendidikan Islam.

Tim Peneliti Puslitbang Pendidikan Agama dan Keagamaan. 2012. Masalah Sosial Keagamaan Peserta Didik SLTA Pulau Jawa dan Sulawesi. Jakarta: Puslitbang Pendidikan Agama dan Keagamaan.

Tim Peneliti Puslitbang Pendidikan Agama dan Keagamaan. 2011. Studi Paham Keagamaan di Sekolah Menengah Atas dan Madrasah Aliyah, Jakarta: Pslitbang Pendidikan Agama dan Keagamaan. Puslitbang

Tim Peneliti Balai Litbang Agama Jakarta. 2011. Kasus Aktual Kehidupan Agama, Studi Pencegahan Dini Konflik Umat Beragama. Jakarta: Balai Litbang Agama Jakarta.

Tholkah, Imam dan Mursyid Ali (eds). 2002. Konflik Sosial bernuansa Agama di Indonesia.Jakarta: Puslitbang Kehidupan Beragama - Badan Litbang dan Diklat Kementerian Agama.
Tholkhah, Imam. 2008. Manusia, Agama dan Perdamaian.Jakarta: Alghazali

Tholkhah, Imam. 2005. Mewaspadai dan Mencegah Konflik Antar Umat Beragama. Jakarta: Badan Litbang Agama dan Diklat Kementerian Agama.

Tholkhah, Imam. 2010. Ahlak Pendidikan Islam. Jakarta: Titian Pena.

Wahyuni, Sari. 2012. Qualitative Research Method - Theory and Practice. Jakarta: Penerbit Salemba empat.

Wibisono, Abd. Fatah dkk. 2010. Islam Rahmatan Lil Alamiin- Buku Rujukan Guru PAI Sekolah Menengah Pertama (SMP).Jakarta: Direktorat Pendidikan Agama Islam,

Wibowo, Agus. 2012. Pendidikan Karakter Strategi Membangun Karakter Bangsa Berperadaban, Jakarta: Pustaka Pelajar.

Yakin, Ainul. 2005. Pendidikan Multikultural - Crosss-Cultural Understanding untuk Demokrasi dan Keadilan, Jakarta: Pilar. 